\title{
The differences in thermal profiles between normal and leukemic cells exposed to anticancer drug evaluated by differential scanning calorimetry
}

\author{
Paweł Góralski • Małgorzata Rogalińska • \\ Jerzy Z. Błoński • Edyta Pytel • Tadeusz Robak • \\ Zofia M. Kiliańska $\cdot$ Henryk Piekarski
}

Received: 3 March 2014 / Accepted: 12 June 2014/Published online: 24 July 2014

(C) The Author(s) 2014. This article is published with open access at Springerlink.com

\begin{abstract}
Chronic lymphocytic leukemia (CLL) is a heterogenous disease with an imbalance between apoptosis and cell proliferation. Therefore, the main goal in CLL therapy is to induce apoptosis and effectively support this process in transformed B lymphocytes. In the current study, we have compared differential scanning calorimetry (DSC) profiles of nuclei isolated from CLL cells and normal mononuclear cells exposed to cladribine or fludarabine combined with mafosfamide (CM; FM), and additionally to $\mathrm{CM}$ combined with monoclonal antibody-rituximab (RCM) for $48 \mathrm{~h}$, as well as in culture medium only (controls). Under current study, the mononuclear cells from peripheral blood (PBMCs) of healthy individuals have been included. The obtained results have shown the presence of thermal transition at $95 \pm 5{ }^{\circ} \mathrm{C}$ in most of nuclear preparations $(92.2 \%)$ isolated from blood of CLL patients. This thermal characteristic parameter was changed after drug exposure, however, to a different extent. These thermal changes were accompanied by the decrease of cell viability, an elevation of apoptosis rate and the changes in expression/proteolysis of poly(ADP-ribose)polymerase-
\end{abstract}

Paweł Góralski and Małgorzata Rogalińska should be considered jointly as the first authors.

P. Góralski · H. Piekarski ( $ه)$

Department of Physical Chemistry, University of Lodz, 165 Pomorska Str., 90-236 Lodz, Poland

e-mail: kchfpiek@uni.lodz.pl

M. Rogalińska · E. Pytel · Z. M. Kiliańska

Department of Cytobiochemistry, University of Lodz, 141/143 Pomorska Str., Lodz, Poland

J. Z. Błoński · T. Robak

Department of Hematology, Medical University of Lodz, 2

Ciołkowskiego Str., Lodz, Poland 1-main marker of apoptosis. Importantly, in DSC profiles of nuclear preparations of PBMCs from blood of healthy donors exposed to investigated drug combinations and control CLL cells, the lack of such changes was observed. Our results confirmed that DSC technique complemented with other biological approaches could be helpful in tailoring therapy for CLL patients.

Keywords Chronic lymphocytic leukemia - Differential scanning calorimetry · Anti-leukemic tailored therapy · Purine analogs $\cdot$ Mafosfamide $\cdot$ Rituximab

\section{Introduction}

The differences in disease development and alterations in chronic lymphocytic leukemia (CLL) cell signaling, as well as microenvironment could be a reason of ineffective chemotherapy [1-3]. Moreover, the coexistence of two populations of quiescentin peripheral blood and cycling cells in germinal centers of bone marrow bring the problem of successive treatment to be even more complicated [4]. Part of CLL patients display resistance for first line of therapy, and because of that, tailoring therapy before drugs administration could be a chance to choose an effective type of curing [5]. New therapies directed toward CLL indicating mainly the potential to induce apoptosis [6]. There are growing list of helpful markers that can be applied not only in the monitoring of disease and its progression, but also in prediction of the remission duration [7, 8]. Very recently, it has been published that microRNA-miR-155 could be associated with the progression of monoclonal B lymphocytosis in CLL. Of special importance is the fact that miR-155 overexpression in plasma could become a marker of patient's weak response to therapy [9]. 

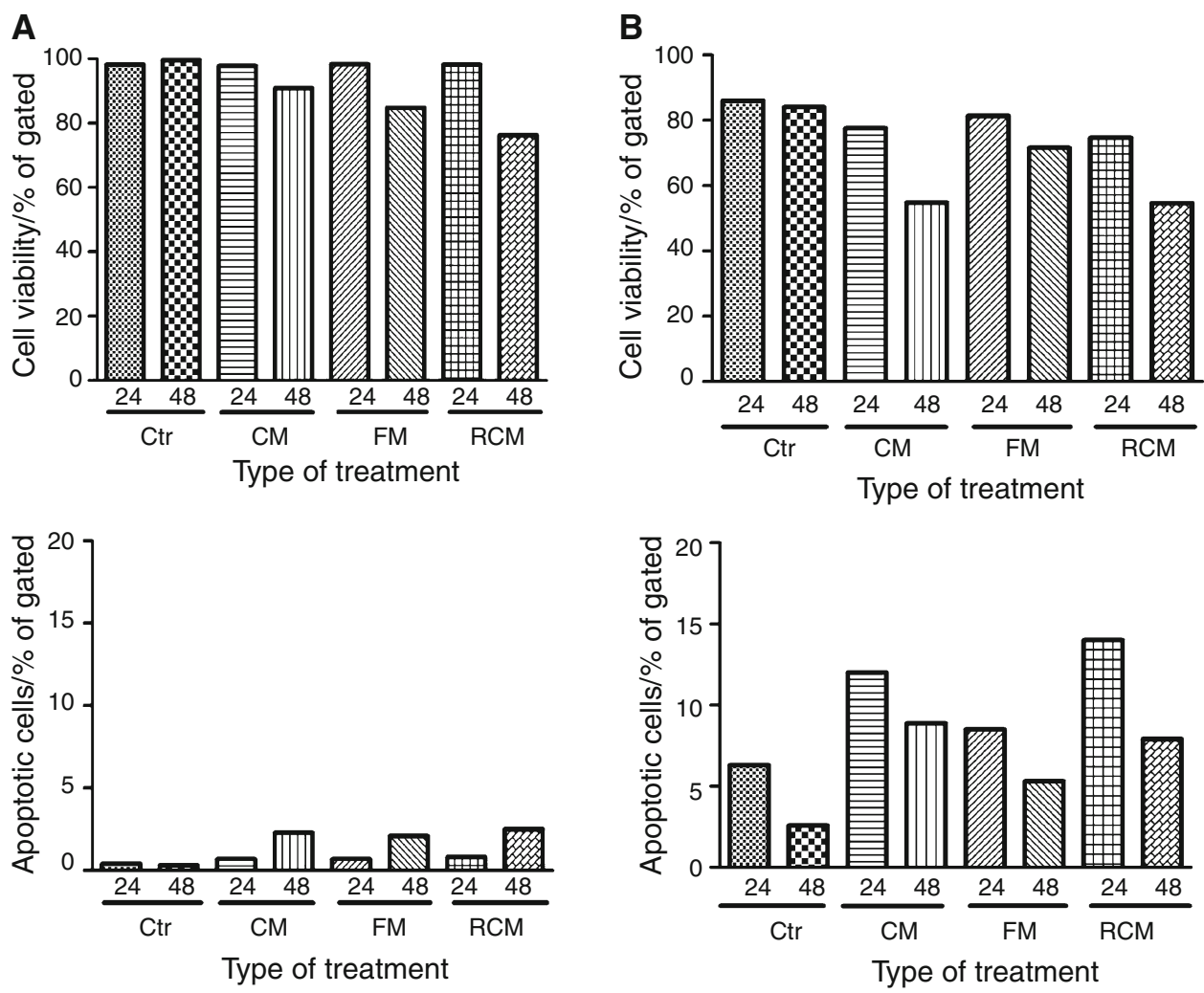

Fig. 1 Viability and apoptosis rate of normal (a) and leukemic (b) PBMCs after exposure to: CM (cladribine + mafosfamide), FM (fludarabine + mafosfamide), and RCM (rituximab + cladribine + mafosfamide) or without drugs (Ctr) for $48 \mathrm{~h}$

Differential scanning calorimetry (DSC) is simple and a relatively fast technique which has appeared to be useful in the research of various medical/biological areas. Interestingly, a typical curve of blood plasma has been established for healthy subjects, whereas for sick individuals, including cancer patients, it was reported to differ [10-12]. This thermal analysis has been applied for study of interactions between gembitabine and phospholipid bilayers [13]. DSC is able to monitor macromolecules denaturation and condensation status of nuclear components of intact nuclei $[14,15]$. DSC technique precisely measures the heatinduced conformational transitions of biomolecules/cellular structures and allows the evaluation of the thermodynamic parameters in nuclear components such as constrained and relaxed DNA, protein-nucleic acid interactions, and scaffolding structures $[16,17]$.

Our previously published results revealed the differences in DSC profiles between normal and leukemic nuclear preparations [18]. It was also reported that in DSC scans of nuclear fraction preparations isolated from mononuclear cells of peripheral blood (PBMCs) of healthy donors, a main transition at $83{ }^{\circ} \mathrm{C}$ was observed. Interestingly, in advanced stage of CLL for majority of patients, the additional thermal transition at about $93{ }^{\circ} \mathrm{C}$ was noticed [18].
In the current study, we have compared curves of nuclear fraction preparations from normal and leukemic PBMCs after their exposure to three drug combinations currently administered in hematooncology, i.e., purine analogs (cladribine or fludarabine) combined with alkylating agent-mafosfamide (active in vitro form of cyclophosphamide; $\mathrm{CM}, \mathrm{FM}$ ), and $\mathrm{CM}$ combined with monoclonal antibody-rituximab (RCM) for $48 \mathrm{~h}$. Up to now, DSC was applied to small groups of patients [18, 19, 21]. The interest in using DSC on cell nuclei/blood plasma in disease diagnostics is high, as this technique is non-invasive for sick individuals and has a potential to monitor the changes in the thermal profiles of examined samples.

\section{Experimental}

\section{Material}

Peripheral blood samples from 5 CLL patients were collected before administration with RCC (rituximab + cladribine + cyclophosphamide). For statistical analysis, data from 64 CLL patients enrolled in the trials since 2005 were included. Simultaneously, mononuclear 
A

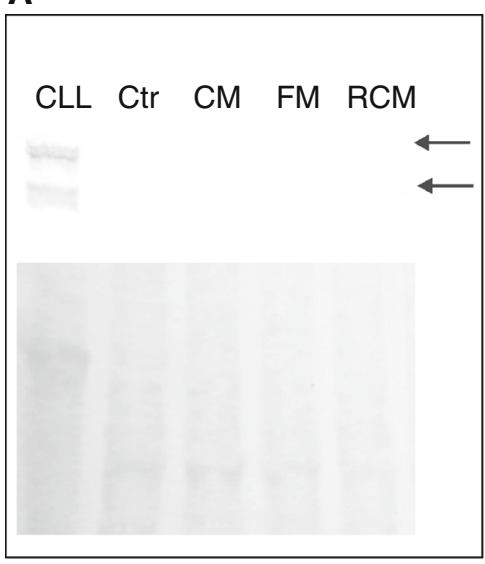

Fig. 2 Changes in apoptotic marker PARP-1 expression in normal (a) and CLL (b) of PBMC lysates after exposure to: CM (cladribine + mafosfamide), FM (fludarabine + mafosfamide), and $\mathrm{RCM}$ (rituximab + cladribine + mafosfamide) or without drugs $(\mathrm{Ctr})$ for $48 \mathrm{~h}$. Protein samples were loaded on $8.0 \%$ polyacrylamide gels

cells were isolated from blood of healthy donors. The PBMC samples were separated using Histopaque-1077 (Sigma-Aldrich, St. Louis, MO, USA) according to manufacturers' procedure. The pelleted cells were washed with phosphate-buffered saline (PBS) and resuspended in RPMI medium. PBMCs from blood of healthy donors and leukemic patients were exposed for $48 \mathrm{~h}$ to combinations: $\mathrm{CM}$ (cladribine + mafosfamide), FM (fludarabine + mafosfamide), and RCM (rituximab + cladribine + mafosfamide) at chosen doses as described previously $[19,20]$. The study was approved by the Local Ethics Committee of the Medical University of Lodz (No. RNN/143/10/KE); patients signed a declaration of consent.

Cell viability and apoptotic cell determination

The cell viability and apoptotic rate of PBMC samples after drug exposure or in culture medium only for $48 \mathrm{~h}$ were assessed by flow cytometry using Vybrant Apoptosis Assay \#4 (Molecular Probes, Inc., Eugene, OR). Evaluation of both parameters was performed on 10,000 cells/sample in each experiment.

\section{Preparation of nuclear fraction}

The pelleted normal and leukemic drug-treated PBMC samples were rinsed with cold PBS and then suspended in isotonic sucrose solution containing $5 \mathrm{mM} \mathrm{MgCl}_{2}, 0.5 \%$ Triton X-100, $50 \mathrm{mM}$ Tris- $\mathrm{HCl}(\mathrm{pH} 7.4)$, and protease inhibitors as previously described [19]. Cell samples were homogenized in a Potter homogenizer. The cell homogenates were centrifuged at $800 \times g$ for $8 \mathrm{~min}$, resulting in the pellets, crude nuclear fraction preparations.
B

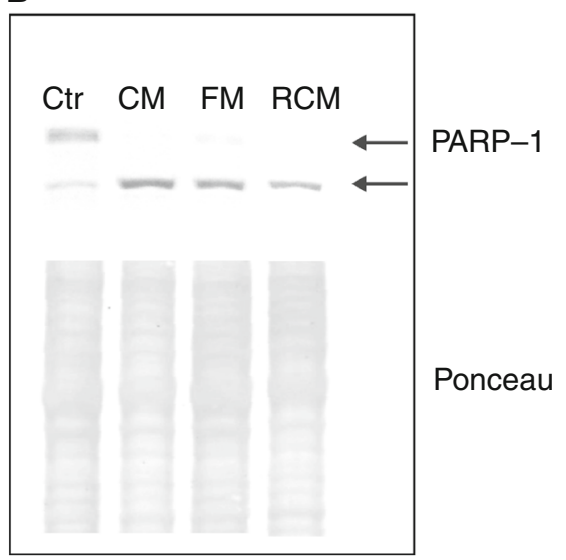

(50 $\mu \mathrm{g} /$ lane). Proper protein transfer was confirmed by Ponceau $\mathrm{S}$ staining (bottom). Blots were incubated with anti-PARP antibody. Immune complexes were detected using AP-linked secondary antibodies after development of color reaction. The positive control of PARP expression (CLL cell lysate from p.23) in part A was performed

Preparation of cell lysates; protein electrophoresis and immunoblotting

Normal and leukemic PBMC samples were lysed in the buffer containing $10 \mathrm{mM}$ Tris- $\mathrm{HCl}(\mathrm{pH} 7.5), 300 \mathrm{mM}$ $\mathrm{NaCl}, 1 \%$ Triton X-100, $2 \mathrm{mM} \mathrm{MgCl}$, and $0.1 \mathrm{M}$ ditiotreitiol and protease inhibitor cocktail. Protein samples $(40 \mu \mathrm{g})$ were separated by sodium-dodecyl sulfate SDSpolyacrylamide gels (SDS-PAGE) and blotted onto Immobilon $\mathrm{P}$ membranes. Equal protein loading and protein transfer were confirmed by Ponceau S staining. To avoid non-specific protein binding sites, the membranes were saturated with $5 \%$ non-fat dry milk in TBS (10 mM Tris$\mathrm{HCl}, \mathrm{pH} 7.5,150 \mathrm{mM} \mathrm{NaCl}$ ) for at least $1 \mathrm{~h}$ at room temperature. After extensive washing in TBS containing $0.05 \%$ Tween-20 (TBST), blots were incubated with specific primary antibodies at the appropriate final dilution. The immune complexes were detected using AP-coupled secondary antibodies after incubating with substrate solution according to the technique previously described [19].

\section{Differential scanning calorimetry (DSC)}

\section{Preparation of samples}

Samples of the nuclear fraction isolated from normal and leukemic PBMCs were incubated for $48 \mathrm{~h}$ with or without (controls; Ctr) anticancer agents and prepared for calorimetric tests by the Almagor and Cole procedure [11]. Nuclear pellets were transferred into stainless steel sample pans $(300 \mu \mathrm{l})$ and hermetically sealed. The dry mass content in nuclear fraction constitute about 3-6\% of whole nuclear 
A

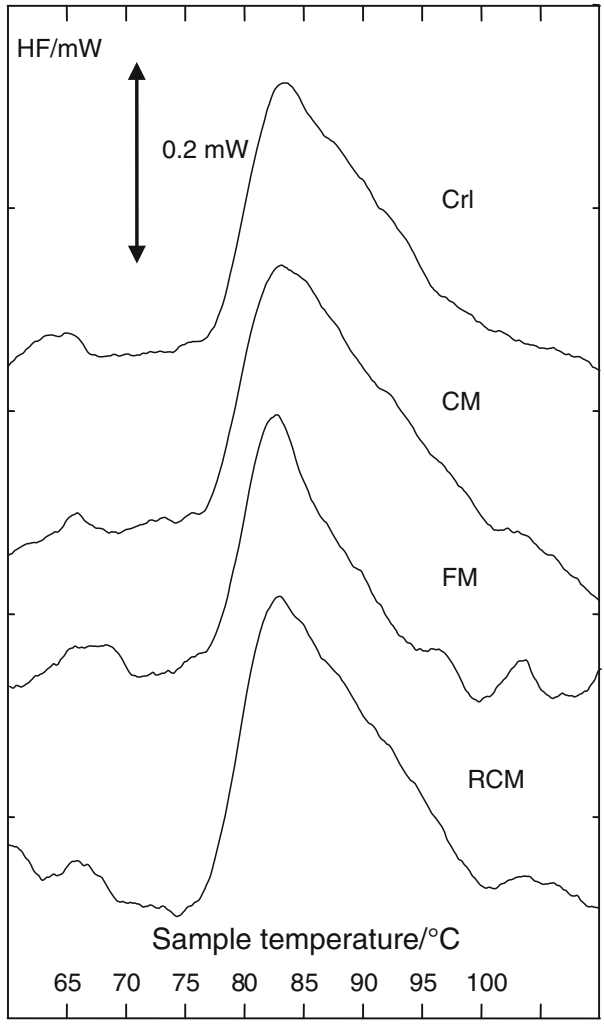

Fig. 3 Differential scanning calorimetry profiles of normal (a) and CLL (b) of nuclear preparations isolated from PBMCs after exposure to: $\mathrm{CM}$ (cladribine + mafosfamide), FM (fludarabine + mafosfamide),

pellet. In analyzed probes, the nuclear fraction consisted about $0.5 \mathrm{mg}$ of DNA. Usually, nuclear samples were frozen and stored up to few weeks in $-20^{\circ} \mathrm{C}$. The storage of nuclear preparations at low temperature did not change the shape of its thermal profile in comparison with freshly prepared ones and still allow for a correct interpretation.

DNA concentration in nuclear pellet was determined by the classical spectrophotometric method (UV) on the basis of the absorption band at $260 \mathrm{~nm}$. For this purpose, Specord 40 spectrophotometer (Jena, Germany) was used. The scanning rate was $2 \mathrm{~nm} \mathrm{~s}^{-1}$ and the resolution $0.1 \mathrm{~nm}$. The sample probes were measured in $1 \mathrm{~cm}$ cells in the range of 260-320 nm. Due to the complex composition and sometimes also the optical heterogeneity of the analyzed samples, the absorbance at $260 \mathrm{~nm}$ was corrected for absorbance baseline at $320 \mathrm{~nm}$.

\section{Measurements}

Calorimetric experiments were performed on a Setaram TG-DSC 111 calorimeter (Caluire, France) from 293.15 to $403.15 \mathrm{~K}$ (20 to $130{ }^{\circ} \mathrm{C}$ ) at a scanning rate $R$ of
B

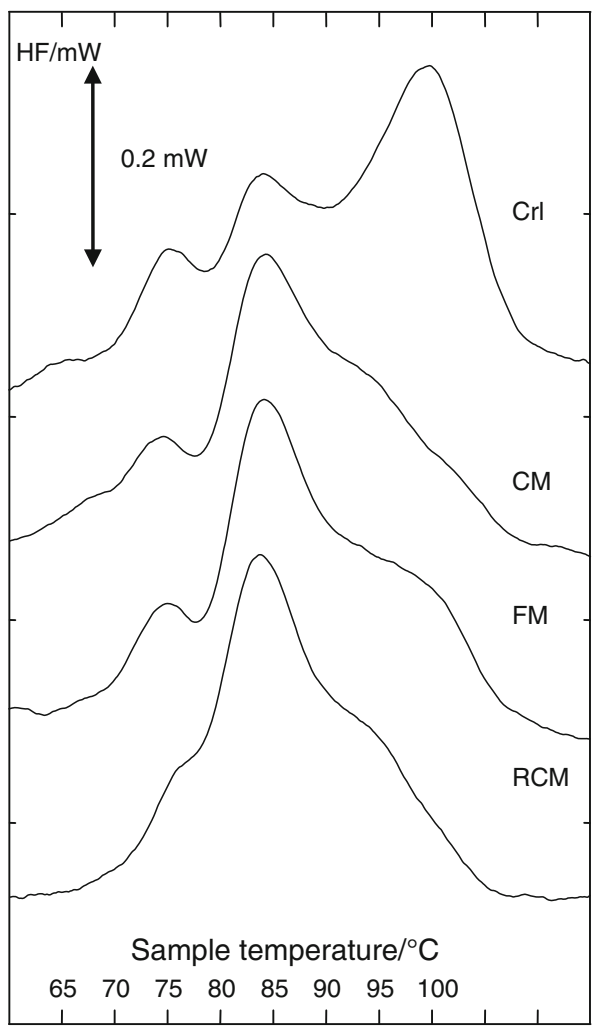

and RCM (rituximab + cladribine + mafosfamide) or without drugs (Ctr) for $48 \mathrm{~h}$

$5{ }^{\circ} \mathrm{C} \mathrm{min}^{-1}\left(0.083{ }^{\circ} \mathrm{C} \mathrm{s}^{-1}\right)$ as reported previously [19, 22]. The temperature calibration of the calorimeter was performed using the melting points of several standard materials [23] such as gallium, indium, naphthalene, and tin. The temperature accuracy is estimated to be $\pm 0.1 \mathrm{~K}$. For calibration of heat flow signal, a sapphire standard was used. During the measurement, the cells were purged by dry nitrogen with a flow rate of $1.7 \mathrm{~mL} \mathrm{~s}^{-1}$. Calorimetrical measurements were consisted of two successive experimental sequences of heating-cooling. During first heating scan, the denaturation process occurred, while the second one was considered as an individual for each experiment baseline. The difference in heat flow signal between first and second scan was a base for analysis of anticancer agent efficacy.

Statistical analysis

The statistical analysis of presence/absence of thermal transition at $95 \pm 5{ }^{\circ} \mathrm{C}$ between nuclear samples preparations from leukemic and healthy donor cells was performed by two-tailed Fisher exact test. 


\section{Results and discussion}

Exposure of CLL cells to anticancer drugs reflects their susceptibility to anticancer treatment

The aim of current study was to compare anticancer drug effects on normal and leukemic PBMC cells by the determination of cell viability, apoptosis rate, differential scanning calorimetry profiles, and expression of known apoptotic marker-PARP-1.

PBMCs samples isolated from the blood of CLL patients qualified for the first chemotherapy cycle were incubated in vitro with combinations of purine analog (cladribine or fludarabine) with the active form of cyclophosphamidemafosfamide (CM or FM) and RCM (rituximab + cladribine + mafosfamide) for $48 \mathrm{~h}$. The exposure of CLL cell samples to the above three drug combinations reflects the differences in cell viability, as well as apoptosis rate (Fig. 1b).

Interestingly, in PBMCs from blood of healthy donors exposed to above drug combinations, a slight decrease of cell viability, as well as marginal changes in apoptotic cell number and proteolytic cleavage of apoptosis markerpoly(ADP-ribose)polymerase-1 (PARP-1) were observed (Figs. 1a, 2a). The obtained data suggest that the examined anticancer drugs direct their action mainly toward leukemic cells via apoptosis induction (Figs. 1b, 2b). It has been previously published by our group that characteristic thermal transition at about $93{ }^{\circ} \mathrm{C}$ in nuclear samples from CLL cells appeared in high percentage $(74 \%)$ of patients with advanced/aggressive stage of this hematological cancer [18]. Since 2005, as the continuation of thermal analysis of nuclear preparations isolated from PBMCs samples of 64 patients with advanced stage of CLL, the presence of above thermal transition at $95 \pm 5{ }^{\circ} \mathrm{C}$ was observed in $59(92.2 \%)$ nuclear samples. Moreover, in most examined nuclear samples, i.e., 40 of $64(62.5 \%)$, this transition represented main one in thermal profile. (see exemplary case, Fig. 3a, b). It should be underscored that this thermal peak does not appear in 16 $(100 \%)$ nuclear samples isolated from PBMCs of healthy individuals. Among parameters describing thermal characteristics of leukemic versus normal nuclear samples, the transition $95 \pm 5{ }^{\circ} \mathrm{C}$ was found in CLL cells with a high statistical significance $(p<0.0001)$.

Decrease/lack of thermal transition at $95 \pm 5{ }^{\circ} \mathrm{C}$ accompanies CLL cell apoptosis

The changes in DSC scans of CLL nuclear preparations exposed to the examined drug combinations correlated with viable cell number reduction, apoptosis rate, and the cleavage of PARP-1, reflecting the potential efficacy for FM, CM, and RCM. However, an addition of rituximab in vitro to leukemic cell cultures with $\mathrm{CM}$, i.e., combination RCM, the option used often in the immunochemotherapy in hematological clinics (RCC) [25], was not very spectacular (Figs. 1-3).

Thermal profiles of PBMC nuclear preparations from blood of healthy donors after exposure to drugs display strong similarity

The profound analysis of thermal profiles of nuclei from mononuclear cell samples from blood of healthy donors exposed to CM, FM, and RCM for $48 \mathrm{~h}$, and control cells (incubated in culture medium only) revealed a strong similarity (see Fig. 3a). Importantly, the combining data of DSC profiling with cell viability, apoptosis rate, and PARP-1 expression confirmed significant sensitivity of studied drug combinations toward CLL cells (Figs. 1b, 3b), displaying only a marginal activity against PBMCs of healthy individuals.

Our results confirmed that DSC technique combined with other approaches could be helpful in the choice of anti-leukemic strategy of CLL patients' therapy to avoid ineffective drug application [22, 24].

To sum up, our results and the data published by other scientists have identified specific disease-related calorimetric characteristics; however, the validation of this technique as a useful and well-applicable tool for disease diagnostics and monitoring requires further studies $[10-12,18,19,24,26]$.

Acknowledgements Research was sponsored by Grant from the Polish National Science Centre (No. 2011/01/B/NZ/0102); Results of presented study were partially presented in oral presentation on 2nd Central and Eastern European Conference on Thermal Analysis and Calorimetry in Vilnius, Lithuania, 2013.

Open Access This article is distributed under the terms of the Creative Commons Attribution License which permits any use, distribution, and reproduction in any medium, provided the original author(s) and the source are credited.

\section{References}

1. Scielzo C, Hacken ET, Bertilaccio MTS, Muzio M, Calissano C, Ghia P, Caligaris-Cappio F. How the microenvironment shapes chronic lymphocytic leukemia: the cytoskeleton connection. Leuk Lymph. 2010;51:1371-4.

2. Tong W-G, Wierda WG, Lin E, Kuang SQ, Bekele BN, Estrov Z, Wei Y, Yang H, Keating MJ, Garcia-Manero G. Genome-wide DNA methylation profiling of chronic lymphocytic leukemia allows identification of epigenetically repressed molecular pathways with clinical impact. Epigenetics. 2010;5:499-508.

3. Longo PG, Laurenti L, Gobessi S, Sica S, Leone G, Efremov DG. The Akt/Mcl-1 pathway plays a prominent role in mediating antiapoptotic signals downstream of the B-cell receptor in chronic lymphocytic leukemia B cells. Blood. 2008;111:846-55. 
4. Klein U, Dalla-Favera R. Germinal centres: role in B-cell physiology and malignancy. Nat Rev Immunol. 2008;8:22-33.

5. Veliz M, Pinilla-Ibarz J. Treatment of relapsed or refractory chronic lymphocytic leukemia. Cancer Control. 2012;19:37-53.

6. Chen R, Plunkett W. Strategy to induce apoptosis and circumvent resistance in chronic lymphocytic leukemia. Best Pract Res Clin Haematol. 2010;23:155-66.

7. Rassenti LZ, Jain S, Keating MJ, Wierda WG, Grever MR, Byrd JC, Kay NE, Brown JR, Gribben JG, Neuberg DS, He F, Greaves AW, Rai KR, Kipps TJ. Relative value of ZAP-70, CD38, and immunoglobulin mutation status in predicting aggressive disease in chronic lymphocytic leukemia. Blood. 2008;112:1923-30.

8. Shanafelt TD, Rabe KG, Kay NE, Zent CS, Jelinek DF, Reinalda MS, Schwager SM, Bowen DA, Slager SL, Hanson CA, Call TG. Age at diagnosis and the utility of prognostic testing in patients with chronic lymphocytic leukemia. Cancer. 2010;116:4777-87.

9. Ferrajoli A, Shanafelt TD, Ivan C, Shimizu M, Rabe KG, Nouraee N, Ikuo M, Ghosh AK, Lerner S, Rassenti LZ, Xiao L, Hu J, Reuben JM, Calin S, You MJ, Manning JT, Wierda WG, Estrov Z, O'Brien S, Kipps TJ, Keating MJ, Kay NE, Calin GA. Prognostic value of miR-155 in individuals with monoclonal B-cell lymphocytosis and patients with B-cell chronic leukemia. Blood. 2013;122:1891-9.

10. Garbett NC, Miller JJ, Jenson AB, Chaires JB. Calorimetric outside the box: a new window into the plasma proteome. Biophys J. 2008;94:1377-83.

11. Michnik A, Drzazga Z, Michalik K, Barczyk A, Santura I, Sozańska E, Pierzchała W. Differential scanning calorimetry study of blood serum in chronic obstructive pulmonary disease. J Therm Anal Calorim. 2010;102:57-60.

12. Fekecs T, Zapf I, Ferencz A, Lorniczy D. Differential scanning calorimetry (DSC) analysis of human plasma in melanoma patients with or without regional lymph node metastases. J Therm Anal Calorim. 2012;108:149-52.

13. Pili B, Bourgaux C, Meneau F, Couvreur P, Ollivon M. Interaction of anticancer drug gemcitabine with phospholipid bilayers. J Therm Anal Calorim. 2009;98:19-28.

14. Sturtevant JM. Biochemical applications of differential scanning calorimetry. Ann Rev Phys Chem. 1987;38:463-88.

15. Almagor M, Cole RD. Differential scanning calorimetry of nuclei as a test for the effects of anticancer drugs on human chromatin. Cancer Res. 1989;49:5561-6.

16. Balbi C, Abelmoschi ML, Gogioso L, Parodi S, Barboro P, Cavazza B, Patrone E. Structural domains and conformational changes in nuclear chromatin: a quantitative thermodynamic approach by differential scanning calorimetry. Biochemistry. 1989;28:3220-7.
17. Allera C, Lazzarini G, Patrone E, Alberti I, Barboro P, Sanna P, Melchiori A, Parodi S, Balbi C. J Biol Chem. 1997;272: 10817-22.

18. Rogalińska M, Góralski P, Kobylińska A, Błoński JZ, Hanausek M, Walaszek Z, Piekarski H, Robak T, Kiliańska ZM. Changes in leukemic cell nuclei revealed by differential scanning calorimetry. Leuk Lymph. 2005;46:121-8.

19. Rogalinska M, Goralski P, Wozniak K, Bednarek JD, Blonski JZ, Robak T, Piekarski H, Hanausek M, Walaszek Z, Kilianska ZM. Calorimetric study as a potential test for choosing treatment of B-cell chronic lymphocytic leukemia. Leuk Res. 2009;33:308-14.

20. Furlan A, Villanova F, Pietrogrande F, Caladin M, Sanzari M, Vianello F. Low-dose fludarabine increases rituximab cytotoxicity in B-CLL cells by triggering caspases activation in vitro. Leuk Lymph. 2010;51:107-13.

21. Chen R, Plunkett W. Strategy to induce apoptosis and circumvent resistance in chronic lymphocytic leukemia. Best Pract Res Clin Haematol. 2010;23:155-66.

22. Rogalińska M, Błoński JZ, Komina O, Góralski P, Żołnierczyk JD, Piekarski H, Robak T, Kiliańska ZM, Węsierska-Gądek J. R-roscovitine (Seliciclib) affects CLL cells more strongly than combinations of fludarabine or cladribine with cyclophosphamide: inhibition of CDK7 sensitizes leukemic cells to caspasedependent apoptosis. J Cell Biochem. 2010;109:217-35.

23. Sabbah R, Xu-Wu A, Chickos JS, Planas Leitão ML, Roux MV, Torres LA. Reference materials for calorimetry and differential thermal analysis. Thermochim Acta. 1999;331:93-204.

24. Rogalińska M, Franiak-Pietryga I, Błoński JZ, Góralski P, Maciejewski H, Janus A, Robak P, Mirowski M, Piekarski H, Robak T, Kiliańska ZM. Toward personalized therapy for chronic lymphocytic leukemia: DSC and cDNA microarray assessment of two cases. Canc Biol Ther. 2013;14:1-7.

25. Robak T, Smolewski P, Cebula B, Szmigielska-Kaplon A, Chojnowski K, Blonski JZ. Rituximab combined with cladribine or with cladribine and cyclophosphamide in heavily pretreated patients with indolent lymphoproliferative disorders and mantle cell lymphoma. Cancer. 2006;107:1542-50.

26. Garbett NC, Mekmaysy CS, Helm CW, Jenson AB, Chaires JB. Differential scanning calorimetry of blood plasma for clinical diagnosis and monitoring. Exp Mol Pathol. 2009;86:186-91. 